\title{
A RECRUITMENT POLICIES AND PROCEDURES IN ORGANIZATIONS AND COMPANIES
}

\author{
DR.C.K.Gomathy ,Mr.A.SAI KIRAN, Mr.B.DHEERAJ KUMAR REDDY Mr.CH.ADITYA KARTHIK \\ Sri Chandrasekharendra Saraswathi Viswa Mahavidyalaya , Kanchipuram
}

\begin{abstract}
Employees are an asset to an organization. Nothing can be achieved without a human resource. Every organization strives to intake the best talent and this is possible with different recruitment policies and the procedure involved for each organization is unique for each company based on their requirements which makes it different from others. And even several factors affect them it outline your company preferred hiring practices and promote consistency within your employee recruiting process.
\end{abstract}

Keywords: Recruitment process, Merit, standard, Philosophy

\section{INTRODUCTION}

The work of the recruiting process to meet with the company policies vary from each other and make them unique. The recruitment is securing a supply of possible candidates for jobs in enterprises. It involves different stages and processes of staffing in an organization which continues with policy of a company and finally selection ends with the placements of an individual in a job.

The most important resource which an organization focuses on is human resources. It is the purpose to achieve the optimal goal of a company. The use of human resources through a rational human resources system and programs for staffing and other recruitments. The people who are recruited are the important form of an organization. An effective recruitment process only helps in finding such employees for an organization.

\section{II.PROBLEM STATEMENT}

Recruitment and selection are the most critical and significant human resources function, unless the organization has the best available employee's, else the company will not be able to grow and flourish in the market

The drive and the motivation levels of the employees needs to be high to enable the company to attain its goals. The steps of the recruitment process and selection processes are equally important in attracting and retaining the right talent.

\section{ESSENTIAL FACTORS IN RECRUITMENT}

Recruiting staff is a very costly exercise. It is also an essential part of any business and it pays to do it properly .When organizations choose the right people for the job and train them well to produce the high good and expected results.

Before joining/recruitment for a role one must be clear of the job description and then apply for it, If he was perfectly opted for that role. 
Once all these processes are completed and the procedure is clearly defined then the hiring managers and supervisors should be trained regarding the requirements of the process and policies of a company.

\section{IV.BENEFITS OF HAVING A RECRUITMENT AND SELECTION POLICY IN HRM}

- $\quad$ clarity on the need of organization.

- $\quad$ clarity on hiring policy process.

- $\quad$ right fit for the organization culture.

- $\quad$ sound hiring decisions.

- make best use of employment policy.

- Better productivity by following the principles of a company.

- Better Culture.

- $\quad$ right budgetary calculations.

- clarity on approach to be taken by all stakeholders.

\section{V.FACTORS THAT AFFECT RECRUITMENT POLICIES}

- $\quad$ Organizations budget and financials.

- Recruitment policy of competitors.

- Job Market conditions

- $\quad$ Specific need of the Organization

- $\quad$ Government Regulations

- Employment Policy.

\section{VI.RESULTS}

By observing all these recruitment policies and procedures involved in it as stated above we can say that a company will grow through a large and long policies that meets its needs for recruitment and allows an individual to get placed in a company and even thinks that how they will be helpful for the company and if their skills match with their requirements, they hire the employees by observing several factors. And finally by all these a perfectly fitted employee is placed in a company, It also helps him grow Economically in a great manner.

\section{VII.CONCLUSION}

By observing all the above stated points, One can easily conclude that the recruitment policy has become the costliest exercise for hiring an employee and the way he has to go through to be placed in a company and helps in its economic growth and makes in one's Individual and Economical growth of an Organization.

\section{REFERENCES}

1.Dr.C K Gomathy, Article: A Study on the recent Advancements in Online Surveying, International Journal of Emerging technologies and Innovative Research ( JETIR ) Volume 5 | Issue 11 | ISSN : 2349-5162, P.No:327-331, Nov-2018

2.Dr.C.K.Gomathy,C K Hemalatha, Article: A Study On Employee Safety And Health Management International Research Journal Of Engineering And Technology (Irjet)- Volume: 08 Issue: 04 | Apr 2021

3. Dr.C K Gomathy, Article: A Study on the Effect of Digital Literacy and information Management, IAETSD Journal For Advanced Research In Applied Sciences, Volume 7 Issue 3, P.No-51-57, ISSN NO: 2279-543X,Mar/2018

4. Dr.C K Gomathy, Article: An Effective Innovation Technology In Enhancing Teaching And Learning Of Knowledge Using Ict Methods, International Journal Of Contemporary Research In Computer Science And Technology (Ijcrcst) E-Issn: 2395-5325 Volume3, Issue 4,P.No-10-13, April '2017 
5.Dr.C K Gomathy, Article: Supply chain-Impact of importance and Technology in Software Release Management, International Journal of Scientific Research in Computer Science Engineering and Information Technology ( IJSRCSEIT ) Volume 3 Issue 6 | ISSN : 2456-3307, P.No:1-4, July-2018

\section{AUTHOR'S PROFILE:-}

1.

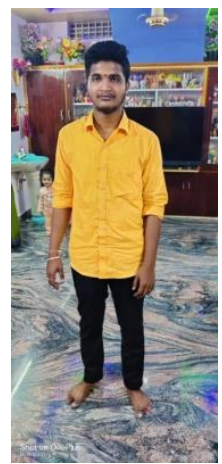

Mr.A.Sai Kiran , Student ,B.E. Computer Science and Engineering , Sri Chandrasekharendra Saraswathi Viswa Maha Vidhyalaya Enathur, Kanchipuram,India.His area of interest in Human Resources Development

2.

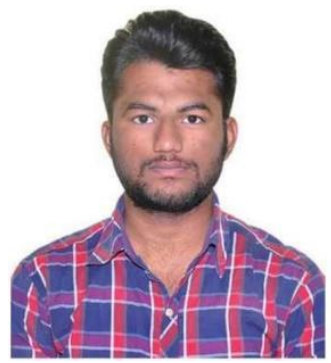

Mr.B.Dheeraj Kumar Reddy, Student , B.E. Computer Science and Engineering , Sri ChandraSekhrendra Saraswathi Viswa MahaVidyalaya Enathur ,Kanchipuram, India. His area of interest in Human Resources Development.
3.

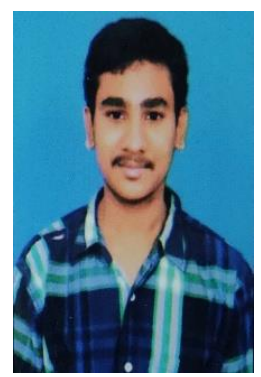

Mr.CH.Aditya Karthik, Student, B.E Computer Science and Engineering, Sri Chandrasekharendra Saraswathi Viswa MahaVidyalaya,Enathur, Kanchipuram, India. His area of interest in Human Resources Development.

4.

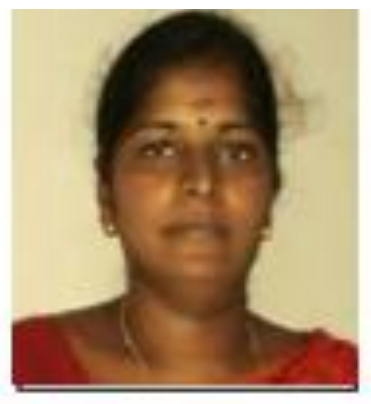

Dr.C.K.Gomathy is Assistant Professor in Computer Science and Engineering at Sri Chandrasekharendra Saraswathi Viswa MahaVidyalaya,Enathur,Kanchipuram,India.Her area of interest in Software Engineering,Web Services, Knowledge Management and IOT. 